\title{
Unilateral Pulmonary Agenesis
}

\author{
J. B. BOOTH* and C. L. BERRY \\ From The Hospital for Sick Children and The Institute of Child Health, Great Ormond Street, London W.C.1
}

Hitherto descriptions of some 200 cases of this condition have been published. In the majority of these reports a single case has been presented in detail together with the investigations showing how the diagnosis was made. Some authors have recorded a small series of cases, and in an effort to increase the number there has often tended to be indiscriminate use of the term agenesis. As a result of this considerable confusion has arisen.

In 1912, Schneider classified the condition according to the extent of the defect. In Group 1 he included only those cases with a complete absence of the lung and bronchus. In Group 2 there was no evidence of any lung tissue, but the beginning of a bronchus was noted as a blind pouch or pit. There has been little difficulty in classifying cases into either of these two groups. In Group 3 he described the bronchus as being essentially normal and ending in a fleshy structure.

Many authors have had difficulty in deciding whether a particular case of this kind should be considered as an example of Group 3 agenesis or hypoplasia. The first cases to be described were all diagnosed post mortem, when it became apparent that in this condition there was also absence of the pulmonary artery on the affected side. It has been suggested, therefore, that if vessels can be demonstrated giving blood to the fleshy structure that this no longer constitutes agenesis and that such a case must therefore be classified as hypoplasia. However, as will be shown later, this is not strictly true, and there remain some cases that defy attempts at inclusion in Schneider's Group 3 or hypoplasia.

More recently (Boyden, 1955) a more practicable classification has been recommended based on the degree of developmental arrest, viz. Group 1 complete absence of one or both lungs (agenesis); Group 2 suppression of all but a rudimentary bronchus (aplasia); Group 3 abortive growth (hypoplasia). In this terminology there is no need to attempt to distinguish between 'type 3 agenesis' and 'hypoplasia'.

\footnotetext{
Received October 13, 1966.

* Present address: Royal National Throat, Nose and Ear Hospital, Gray's Inn Road, London W.C.1.
}

Several authors have compared their cases with those already published (Hurwitz and Stephens, 1937; Smart, 1946; Wexels, 1951 ; Oyamada, Gasul, and Holinger, 1953; Valle, 1955). Until 1950, out of 55 reported cases the diagnosis during life had been made on only 16 occasions (Ingram, Hudson, and Davis, 1950). Since that time, the percentage of diagnoses during life has risen considerably; it remains true, however, that just under half of the patients with this condition die in the first year of life. In several adults dying from other causes, absence of a lung has been demonstrated at necropsy. The condition is thus compatible with long survival. The over-all incidence of this congenital anomaly has proved impossible to estimate (Delarue, Paillas, Abelanet, and Chomette, 1959).

Here 17 cases are recorded, of which 8 are still living and have been followed from infancy. In this series the characteristics of the condition have been illustrated and the associated ipsilateral abnormalities described. As will be seen from Table I, the incidence of anomalies in the living cases is considerably higher than previously reported. The main findings in the whole group are recorded in Table II, the details of those that died in Table III, and of those that still survived in Table IV.

\section{Clinical Examination}

The difficulty of diagnosis depends on the side of the absent lung, the apparent dextrocardia induced by absence of the right lung being a striking clinical finding. When the right lung is absent, the heart is rotated in a clockwise direction and the apex beat is felt in the 3rd or 4th space in the right mid axillary line. Air entry in the underlying left lung is often heard in the right paravertebral and parasternal areas, but is absent in the right axilla, and the right diaphragm is raised. These findings show that with absence of the left lung, the heart sounds are louder than normal over the apex beat.

When examining 5 out of the 9 cases at follow-up, there was obvious flattening of the chest on the affected side with impaired movement on inspiration. It is suggested that the asymmetry of the chest becomes more noticeable in the adult patient 
TABLE I

Distribution of 17 Cases

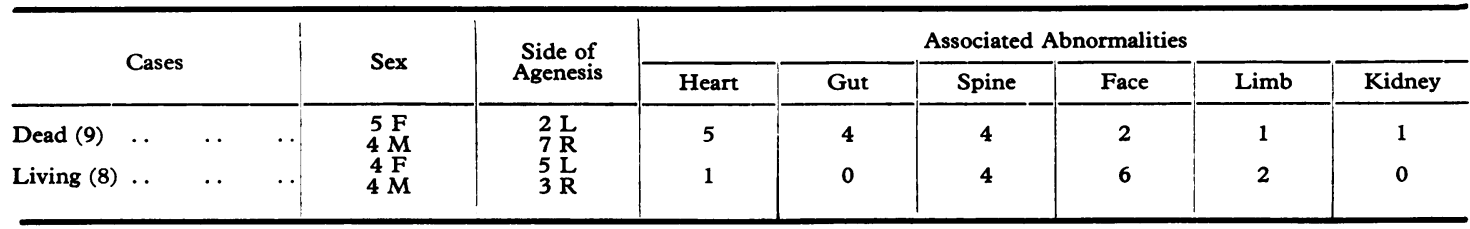

TABLE II

Details of Cases

\begin{tabular}{|c|c|c|c|c|}
\hline Case No. & Age and Sex & $\begin{array}{c}\text { Side of } \\
\text { Agenesis }\end{array}$ & Symptoms and Signs & $X$-ray Findings \\
\hline 1 & 1 dy, $_{,} F$ & Rt. & $\begin{array}{l}\text { Cyanosed from birth; poor } \\
\text { expansion of rt. side of chest; } \\
\text { absent air entry on rt.; heart } \\
\text { sounds maximal at rt. sternal } \\
\text { border }\end{array}$ & $\begin{array}{l}\text { Rib anomalies; multiple } \\
\text { defects of vertebral body } \\
\text { segmentation }\end{array}$ \\
\hline 2 & 5 dy., F & Rt. & $\begin{array}{l}\text { Cyanosed at birth; hypotonic } \\
\text { lower limbs; breath sounds } \\
\text { diminished on rt.; dextrocardia }\end{array}$ & Rt. hemithorax opaque \\
\hline 3 & 2 mth., $M$ & Rt. & $\begin{array}{l}\text { Cyanosed at birth; feeding difficulty; } \\
\text { depressed, poorly moving rt. side } \\
\text { of chest; poor air entry; } \\
\text { heart displaced to rt. }\end{array}$ & Rt. hemithorax opaque \\
\hline 4 & 2 mth., $M$ & Rt. & $\begin{array}{l}\text { Difficulty in breathing during } \\
\text { feeding, dyspnoea following } \\
\text { feeds; air entry absent on rt.; } \\
\text { heart displaced to rt. }\end{array}$ & $\begin{array}{l}\text { Partial herniation of lt. lung } \\
\text { across midline; ?6 lumbar } \\
\text { vertebrae }\end{array}$ \\
\hline 5 & 10 wk., $M$ & Rt. & $\begin{array}{l}\text { Cyanosed at birth; dyspnoea; } \\
\text { convulsions; dextrocardia, loud } \\
\text { systolic murmur }\end{array}$ & $\begin{array}{l}\text { Chest } x \text {-ray film-(see Fig. 6); } 1 \overline{9} \\
\text { pairs of ribs; defective } \\
\text { segmentation of sacrum }\end{array}$ \\
\hline 6 & 9 mth., $M$ & Rt. & $\begin{array}{l}\text { Other abnormalities noted, see } \\
\text { Table III }\end{array}$ & $\begin{array}{l}\text { Anomalies of vertebrae, } \\
\text { kyphosis in dorsal region; } \\
\text { rib anomalies }\end{array}$ \\
\hline 7 & 11 mth., $F$ & Lt. & Other abnormalities, see Table III & $\begin{array}{l}\text { Associated abnormalities of } \\
\text { ribs; disorganization at lt. } \\
\text { inferior radio-ulnar joint } \\
\text { (Fig. 16) }\end{array}$ \\
\hline 8 & 10 yr., $F$ & Rt. & $\begin{array}{l}\text { Flattening of } 1 \text { t. chest developed } \\
\text { during first } 2 \text { yr.; apex beat in } \\
\text { rt. mid-axillary line }\end{array}$ & $\begin{array}{l}\text { Lt. lung herniated across mid- } \\
\text { line anteriorly; angiocardio- } \\
\text { gram; no rt. pulmonary } \\
\text { vessels }\end{array}$ \\
\hline $\begin{array}{c}9 \\
\text { (Brimble- } \\
\text { combe, } \\
\text { 1951, case 3) }\end{array}$ & 4 mth., F & Lt. & $\begin{array}{l}\text { Cyanosis when feeding; dyspnoea; } \\
\text { movements of lt. chest } \\
\text { diminished, breath sounds } \\
\text { markedly diminished on lt.; } \\
\text { heart shifted to lt. }\end{array}$ & $\begin{array}{l}\text { Chest } x \text {-ray film published } \\
\text { previously (Brimblecombe, } \\
\text { 1951) }\end{array}$ \\
\hline 10 & $4 \frac{1}{2}$ yr., M & Lt. & $\begin{array}{l}\text { Dyspnoea of effort; cyanosed at } \\
\text { birth; repeated respiratory } \\
\text { infections as baby, now well; } \\
\text { chest slanting of ribs, flattening } \\
\text { of lt. chest; air entry normal on } \\
\text { rt., and in lt. parasternal region }\end{array}$ & $\begin{array}{l}\text { Lt. hemithorax opaque, } \\
\text { crowding of ribs; rt. lung } \\
\text { herniated anteriorly }\end{array}$ \\
\hline 11 & $7 \frac{1}{2}$ yr., F & Lt. & $\begin{array}{l}\text { Haemorrhage from lower bowel aet. } \\
2 \text { dy.; slight cyanosis on crying; } \\
\text { recurrent chest infections as } \\
\text { infant; increasing scoliosis }\end{array}$ & $\begin{array}{l}\text { Lt. hemithorax opaque (Fig. 5); } \\
\text { reduced in size by scoliosis; } \\
\text { multiple vertebral and rib } \\
\text { abnormalities }\end{array}$ \\
\hline 12 & $7 \frac{1}{2}$ yr., F & Rt. & $\begin{array}{l}\text { Slightly cyanosed after birth; } \\
\text { respiratory infections as an infant; } \\
\text { well for } 5 \text { yr., then pneumonia } \\
\text { (7 yr.); dyspnoea of effort; } \\
\text { rt. chest-infraclavicular hollow, } \\
\text { and slight flattening; } \\
\text { rt. trapezius deficient }\end{array}$ & $\begin{array}{l}\text { Dextrocardia; mediastinum } \\
\text { shifted to rt.; lt. lung } \\
\text { herniated into rt. } \\
\text { hemithorax }\end{array}$ \\
\hline
\end{tabular}

continued 
TABLE II-continued

\begin{tabular}{|c|c|c|c|c|}
\hline Case No. & Age and Sex & $\begin{array}{c}\text { Side of } \\
\text { Agenésis }\end{array}$ & Symptoms and Signs & $X$-ray Findings \\
\hline 13 & 12 yr., $M$ & Lt. & $\begin{array}{l}\text { Minimal respiratory difficulty in } \\
\text { infancy; chest: lt. side flattened; } \\
\text { infraclavicular hollow; trapezius } \\
\text { deficient, lt. scapular more } \\
\text { prominent; air entry in lt. } \\
\text { parasternal region }\end{array}$ & $\begin{array}{l}\text { Lt. hemithorax opaque; } \\
13 \text { pairs ribs, 3rd rib } \\
\text { rudimentary on lt. }\end{array}$ \\
\hline 14 & $17 \frac{1}{2}$ yr., M & Rt. & $\begin{array}{l}\text { Cyanosed at birth; } 3 \text { yr. recurrent } \\
\text { respiratory infections; dyspnoea } \\
\text { of effort; chest flattened on rt., } \\
\text { infraclavicular hollow; trapezius } \\
\text { deficient; air entry in rt. } \\
\text { parasternal area }\end{array}$ & Dextrocardia \\
\hline 15 & 18 yr., M & Rt. & $\begin{array}{l}\text { Well until } 9 \text { mth., then recurrent } \\
\text { pneumonia for several yr.; } \\
\text { dyspnoea of effort; chest: } \\
\text { flattening of rt. side; scoliosis to } \\
\text { rt.; prominent rt. scapular (Fig. 4); } \\
\text { air entry in rt. parasternal area }\end{array}$ & Dextrocardia \\
\hline $\begin{array}{l}16 \\
\text { (Brimble- } \\
\text { combe, } \\
1951, \\
\text { Case } 4 \text { ) }\end{array}$ & 19 yr., F & Lt. & $\begin{array}{l}\text { Cyanosed at birth; dyspnoea of } \\
\text { effort; chest: lt. side flattened, } \\
\text { breast higher than on rt. side; } \\
\text { lt. scapular more prominent; lt. } \\
\text { pectoralis major muscle smaller }\end{array}$ & $\begin{array}{l}\text { Lt. hemithorax opaque; } \\
\text { marked deviation of trachea } \\
\text { and mediastinum to lt.; } \\
\text { rt. cervical rib; T. } 4 \text { and } 5 \\
\text { present as hemivertebrae; } \\
\text { dorsal scoliosis }\end{array}$ \\
\hline $\begin{array}{l}\text { Field, 1946, } \\
\text { Case 1) }\end{array}$ & 23 yr., F & Lt. & $\begin{array}{l}\text { Occasional vomiting in early life; } \\
\text { mentally retarded; chesc: slight } \\
\text { supraclavicular hollow; air entry } \\
\text { in lt. parasternal area; some } \\
\text { deficiency of lt. trapezius }\end{array}$ & $\begin{array}{l}\text { Lt. hemithorax opaque; rt. } \\
\text { lung herniated across mid- } \\
\text { line; spina bifida of T. } 1 \text { and } \\
2 \text {; dorsal scoliosis }\end{array}$ \\
\hline
\end{tabular}

than in the infant, and this may account for the fact that it has not been reported on as many occasions as might be expected when this defect has been discovered in infancy and childhood.

Asymmetry of the chest is well shown in Fig. 1-3. It is less apparent in an adult woman, though in such patients the breast on the affected side may be more conical and less rounded in shape and hang at a slightly higher level than that on the contralateral side.

\section{Investigations}

Chest $x$-ray film. In left-sided agenesis the heart and mediastinum are shifted markedly to that

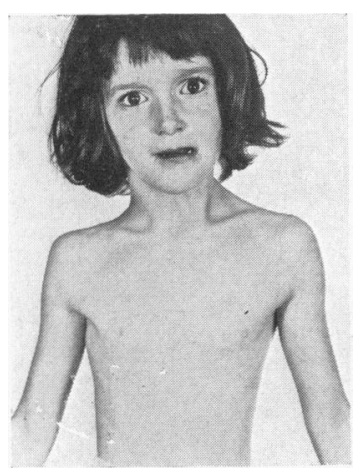

Fig. 1.-Case 12: right agenesis.

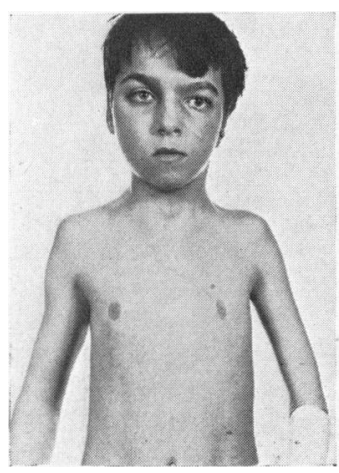

FIG. 2.-Case 13: left agenesis. side. There may or may not be aeration of the apical and paravertebral areas on the affected side, depending on the degree of hypertrophy of the opposite lung.

When the right lung is absent, there is apparent dextrocardia and often herniation of the left lung across the anterior or posterior mediastinum.

On the side of the agenesis it is usual to find the ribs placed closer together and having an imbricated appearance. 13 pairs of ribs are not infrequently encountered and the additional pair may or may not be in the cervical position (Fig. 5 and 6). The apex of the agenetic side is often noted to be filled by the developing thymus gland.

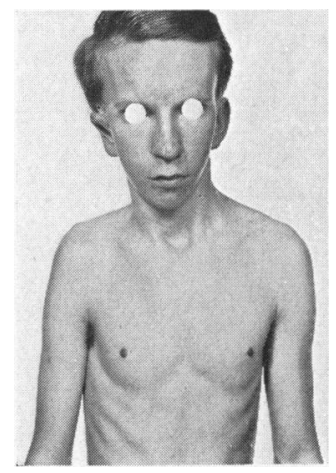

FIG. 3.-Case 14: right agenesis.

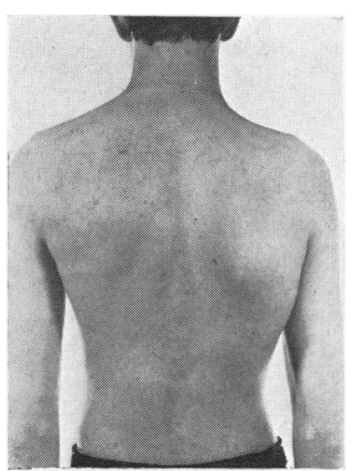

FIg. 4.-Case 15: right agenesis. 
Necropsy a

\begin{tabular}{|c|c|c|c|}
\hline Case No. & Side of Agenesis & Lung & Tracheo-bronchial Tree \\
\hline 1 & Rt. & $\begin{array}{l}\text { Prolongation of lt. lower lobe passed through } \\
\text { deficient mediastinum to rt. sided sac } \\
\text { apparently lined by pleura (Fig. 11) }\end{array}$ & $\begin{array}{l}\text { After origin of bronchus tracheal rings } \\
\text { way to oesophageal mucosa; pit oppo } \\
\text { lt. main bronchus }\end{array}$ \\
\hline 2 & Rt. & $\begin{array}{l}\text { Vestigial rt. lung in paravertebral position, no } \\
\text { bronchus, small vascular connexions }\end{array}$ & $\begin{array}{l}\text { Narrowing of trachea just above carina; } \\
\text { dimple at site of rt. main bronchus }\end{array}$ \\
\hline 3 & Rt. & Lt. lung unilobular, patchy consolidation & $\begin{array}{l}\text { Trachea terminated in lt. bronchus, no } \\
\text { rudimentary } \mathrm{rt} \text {. bronchus }\end{array}$ \\
\hline 4 & Rt. & Absence of rt. lung and pleural cavity (Fig. 12) & $\begin{array}{l}\text { Trachea continued as lt. main bronchus } \\
\text { trace of } \mathrm{rt} \text {. bronchus }\end{array}$ \\
\hline 5 & Rt. & $\begin{array}{l}\text { Necropsy refused; died in congestive heart } \\
\text { failure }\end{array}$ & \\
\hline 6 & Rt. & $\begin{array}{l}\text { Necropsy refused; died after pulmonary } \\
\text { collapse with paradoxical respiration }\end{array}$ & \\
\hline 7 & Lt. & Herniation of rt. lung occupied lt. chest & \\
\hline 8 & Rt. & $\begin{array}{l}\text { Vestigial rt. lung removed at thoracotomy; } \\
\text { lt.-sided compensatory emphysema noted, } \\
\text { with herniation of lung across ant. } \\
\text { mediastinum }\end{array}$ & \\
\hline 9 & Lt. & $\begin{array}{l}\text { No pleural cavity; lt. lung composed of small } \\
\text { node applied to tip of bronchus; rt. lung } \\
\text { large, bilobed }\end{array}$ & $\begin{array}{l}\text { Trachea divided normally; lt. bronchus } \\
6 \mathrm{~mm} \text {. long }\end{array}$ \\
\hline
\end{tabular}

achea continued as lt. main bronchus; no

refused; died in congestive heart

ecropsy refused; died after pulmonary

t.-sided compensatory emphysema noted, with herniation of lung across ant.

pleural cavity; lt. lung composed of small node applied to tip of bronchus; rt. lung large, bilobed

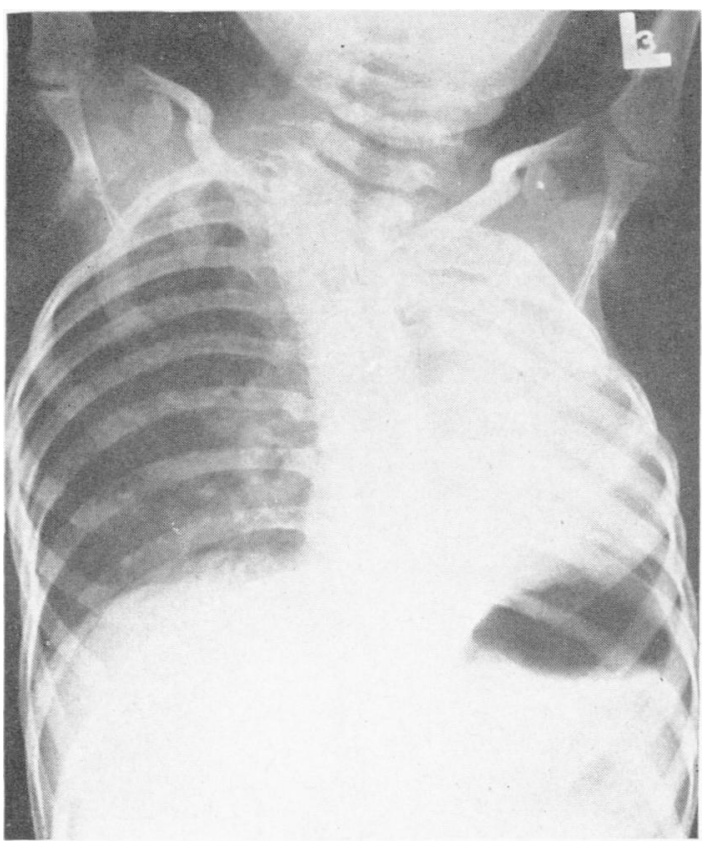

FIG. 5.-Case 11.

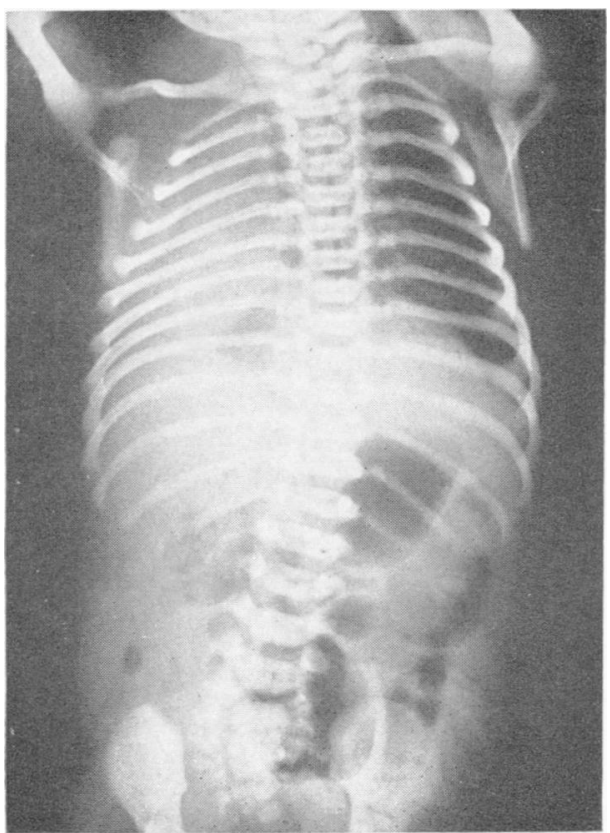

FIg. 6.-Case 5. 
Examination Findings

\begin{tabular}{|c|c|c|}
\hline Heart & Gut & Other Anomalies \\
\hline $\begin{array}{l}\text { Transposition of great arteries; } \\
\text { pulmonary valve atretic, single } \\
\text { pulmonary artery; PDA; ASD }\end{array}$ & $\begin{array}{l}\text { Imperforate anus; oesophageal atresia; } \\
\text { tracheo-oesophageal fistula; annular } \\
\text { pancreas; universal mesentery }\end{array}$ & $\begin{array}{l}\text { Goitre; syndactyly of } 2 \text { nd and } 3 \text { rd toes } \\
\text { of } 1 \mathrm{t} \text {. foot; partial syndactyly of } \\
\text { same toes of } \mathrm{rt} \text {. foot }\end{array}$ \\
\hline $\begin{array}{l}\text { Large pulmonary artery to lt. lung } \\
2 \mathrm{~mm} \text {. diameter vessel to rt. lung; } \\
\text { PDA; persistent lt. SVC }\end{array}$ & $\begin{array}{l}\text { Duodenal atresia with annular pancreas; } \\
\text { universal mesentery; malrotation }\end{array}$ & \\
\hline Small pulmonary artery; VSD & & $\begin{array}{l}\text { Asymmetrical head, low-set ears with } \\
\text { malformed pinnae }\end{array}$ \\
\hline \multirow[t]{3}{*}{ Single pulmonary artery; PDA } & Meckel's diverticulum & $\begin{array}{l}\text { Solitary ectopic kidney in pelvis, in } \\
\text { mid-line, with single ureter entering } \\
\text { bladder at site of rt. uretero-vesical } \\
\text { orifice }\end{array}$ \\
\hline & Imperforate anus & \\
\hline & & $\begin{array}{l}\text { Paraplegic (level T } 10-12) \text {; hamstring } \\
\text { and dorsiflexor contractures; } \\
\text { kyphoscoliosis in thoracic region } \\
\text { (convexity to lt.); asymmetrical head }\end{array}$ \\
\hline \multirow[t]{2}{*}{$\begin{array}{l}\text { Blind lt. pulmonary artery; absent lt. } \\
\text { pulmonary veins; rt. side of heart } \\
\text { hypertrophied }\end{array}$} & & $\begin{array}{l}\text { Asymmetrical skull; lt. side of body } \\
\text { underdeveloped; shortening of lt. } \\
\text { arm; hypotonia; digital positioning } \\
\text { of lt. thumb; lt. sternomastoid } \\
\text { hypoplastic; lt. ptosis }\end{array}$ \\
\hline & & $\begin{array}{l}\text { Anomalies of spine, including } \\
\text { hemivertebra in lower cervical } \\
\text { region, posterior spina bifida at } \mathrm{T} 1 \text {; } \\
\text { anterior spina bifida at } \mathrm{T} 4\end{array}$ \\
\hline $\begin{array}{l}\text { Atrio-ventricular septal defect; patent } \\
\text { foramen ovale }\end{array}$ & & \\
\hline
\end{tabular}

Bronchoscopy and bronchography. In the past, bronchoscopy has frequently been performed to establish the diagnosis. Typical findings are recorded in five of the cases in Table IV. The views which may be seen have recently been recorded photographically (Maisano, 1965). A bronchogram con- firms the type or degree of the malformation which may be particularly difficult to distinguish in Schneider's Groups 2 and 3, when the small atretic bronchus is viewed at endoscopy and found to be full of mucus (Fig. 7 and 8 are typical bronchograms of type 3 agenesis of the left and right lungs, respectively).

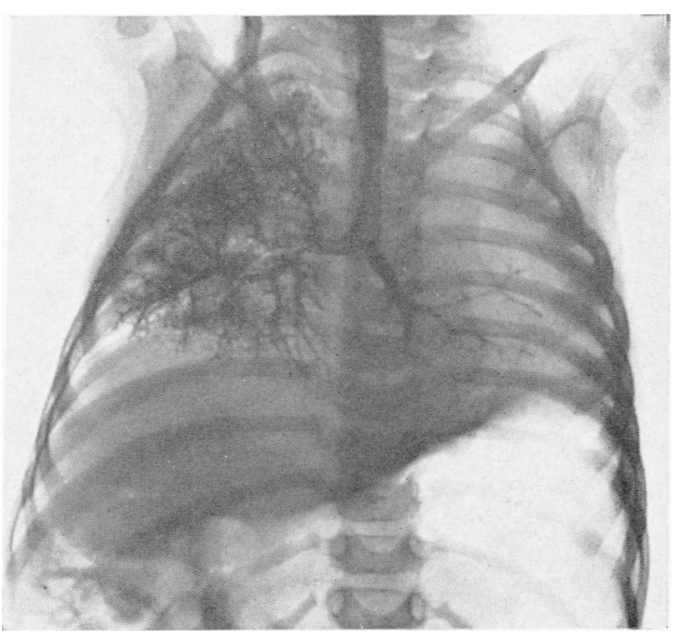

FIg. 7.-Case 7.

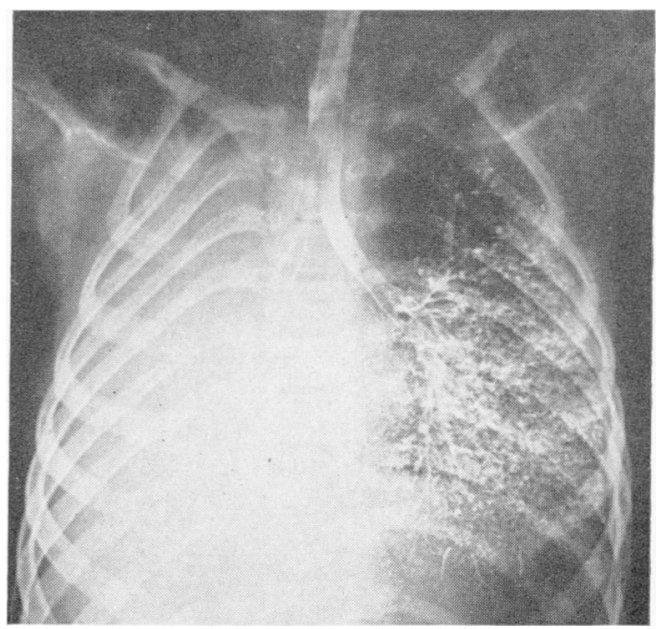

FIG. 8.-Case 15. 
TABLE IV

Other Findings in Survivors

\begin{tabular}{|c|c|c|c|c|}
\hline $\begin{array}{l}\text { Case } \\
\text { No. }\end{array}$ & $\begin{array}{l}\text { Side of } \\
\text { Agenesis }\end{array}$ & Special Investigations & Facial Abnormality & Other Abnormalities \\
\hline 10 & Lt. & $\begin{array}{l}\text { Bronchoscopy: lt. main bronchus } \\
\text { ended in blind stump just } \\
\text { be; ond carina; rt. bronchus } \\
\text { normal }\end{array}$ & & $\begin{array}{l}\text { Partial syndactyly of } 2 \text { nd and } \\
\text { 3rd toes of both feet }\end{array}$ \\
\hline 11 & Lt. & & $\begin{array}{l}\text { Asymmetry; large accessory } \\
\text { auricle of lt. ear }\end{array}$ & $\begin{array}{l}\text { Small hiatus hernia } \\
\text { demonstrated radiologically } \\
\text { during infancy }\end{array}$ \\
\hline 12 & Rt. & $\begin{array}{l}\text { Bronchogram: rt. bronch as } \\
\text { ended blindly just beyond } \\
\text { carina; lt. bronchus normal }\end{array}$ & $\begin{array}{l}\text { Slight asymmetry, with } \\
\text { hypoplasia of } \mathrm{rt} \text {. mandible }\end{array}$ & Bilateral inguinal herniae \\
\hline 13 & Lt. & $\begin{array}{l}\text { Angiocardiography (Fig. 9); } \\
\text { absent tt. pulmonary artery; } \\
\text { no cardiac lesion }\end{array}$ & $\begin{array}{l}\text { Agenesis of lt. side of face and } \\
\text { jaw; underdevelopment of } \\
\text { base of skull; microtia, with } \\
\text { absence of auditory meatus } \\
\text { and middle ear on lt. side } \\
\text { (Fig. } 13 \text { and 14). }\end{array}$ & $\begin{array}{l}\text { Arm: absent lt. radius: } \\
\text { horseshoe-shaped ulna; } \\
\text { poorly developed carpus; } \\
\text { feeble hand, entire arm } \\
\text { weaker than rt., also } \\
\text { smaller (Fig. } 15 \text { and 17) }\end{array}$ \\
\hline 14 & Rt. & & $\begin{array}{l}\text { Asymmetrical; underdevelop- } \\
\text { ment of rt. side of } \\
\text { mandible and maxilla; } \\
\text { rt.-sided deafness }\end{array}$ & $\begin{array}{l}\text { Rt. thumb in digital position, } \\
\text { poor thenar musculature; } \\
\text { reduced span compared to } \\
\text { lt. (Fig. 18) }\end{array}$ \\
\hline 15 & Rt. & $\begin{array}{l}\text { Bronchoscopy: rt. main bronchus } \\
\text { present, ending blindly; } \\
\text { confirmed on bronchography }\end{array}$ & & \\
\hline 16 & Lt. & $\begin{array}{l}\text { Bronchscopy: abnormal origin } \\
\text { of eparterial bronchus (rt. } \\
\text { side); bronchogram: } 1 \mathrm{t} \text {. } \\
\text { bronchus ends blindly } 8 \mathrm{~mm} \text {. } \\
\text { from carina; abnormality on } \\
\text { r1. confirmed and additional } \\
\text { bronchus noted (Fig. } 7 \text { and } \\
\text { 8, published previously) }\end{array}$ & $\begin{array}{l}\text { Lt. cheek less prominent than } \\
\text { rt. }\end{array}$ & PDA ligated at $10 \mathrm{yr}$. of age \\
\hline 17 & Lt. & $\begin{array}{l}\text { Bronchoscopy: trachea narrow, } \\
\text { no lt. main bronchus; rt. } \\
\text { bronchus narrow; broncho- } \\
\text { graphy; lt. bronchus ended } \\
\text { blindly after } 5 \text { mm. (Fig. } 1 \text {, } \\
\text { published previously) }\end{array}$ & Bilateral ptosis & $\begin{array}{l}\text { Microcephaly; bilateral } \\
\text { talipes equinovarus (now } \\
\text { corrected) }\end{array}$ \\
\hline
\end{tabular}

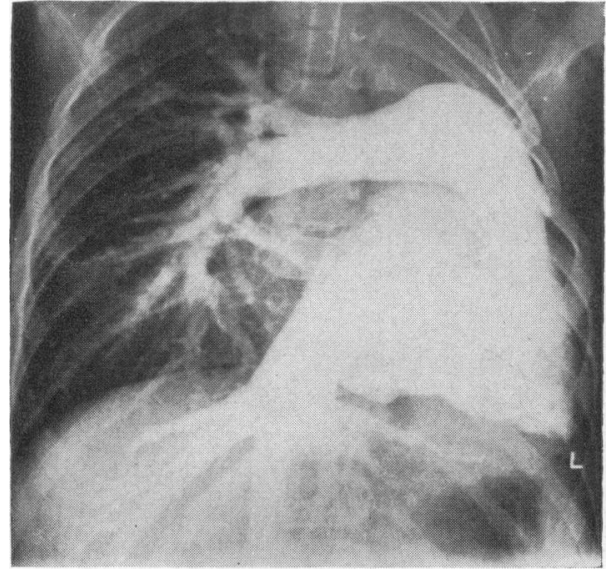

FIG. 9.-Case 13.

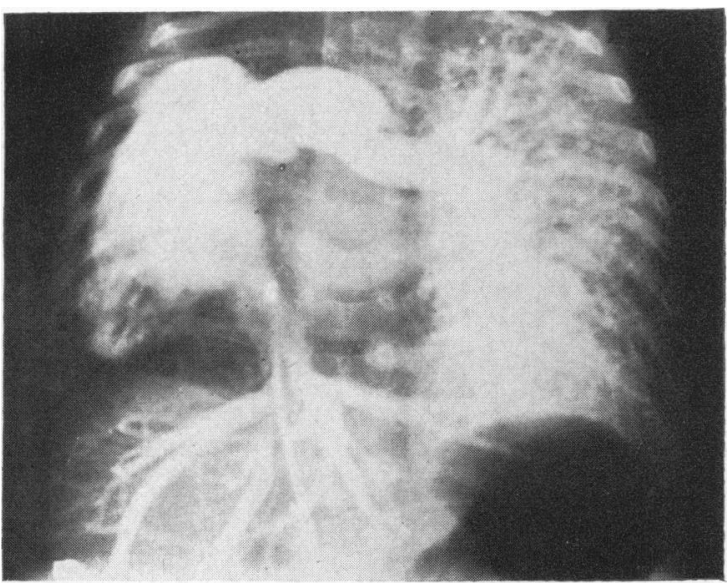

Frg. 10. 
Angiocardiography. This investigation was first performed in a case of hypoplastic left lung by Castellanos and Pereiras in 1942, and since that time it has been used with increasing frequency to demonstrate the absence of a pulmonary arterial supply to the absent lung (Fig. 9 and 10). It has been suggested by Smith and Bech (1958) that when no pulmonary artery can be shown, no pulmonary tissue exists and that the condition is true agenesis; conversely, when a pulmonary blood flow is shown some lung tissue must be present and the condition should be regarded as one of pulmonary hypoplasia. However, it should be remembered that the isolated absence of one of the pulmonary arteries has been reported in patients with two lungs.

\section{Associated Abnormalities}

Cardiovascular system. All the common heart abnormalities accompanying unilateral pulmonary agenesis have been recorded, the most common being patent ductus arteriosus; this was present in 3 of our 9 cases which died (Table III). It was the only cardiac abnormality amongst the living patients and in this case the ductus was tied off at the age of 10. The ductus has been tied off in 3 other recorded cases (Nicks, 1957; Jimenez-Martinez, PérezAlvarez, Pérez-Treviño, Rubio-Alvarez, and De Rubiens, 1965; Nelson, McMillan, and Bharucha, 1967). It has recently been shown that during the attacks of hypoxia, there may be a bi-directional shunt through the patent ductus arteriosus due to pulmonary hypertension whilst permanent reversal of flow through a patent ductus arteriosus has been recorded in a man with left-sided agenesis (Lukas, Dotter, and Steinberg, 1953; Steinberg and Stein, 1966, Case 3).

Reported abnormalities of the great vessels are recorded in Table V.

Gastro-intestinal abnormalities. It might be expected that tracheo-oesophageal fistula was a common accompaniment of unilateral pulmonary agenesis, but only 13 cases have been recorded (Table VI). In only one of our series was a tracheooesophageal fistula found (Fig. 11). This case was remarkable for the fact that the normal tracheal structure gave way imperceptibly to the lower end of the oesophagus and the left bronchus was given off just above the dividing areas; the only similar reported case seems to be that of Wehr (1934). No other gastro-intestinal abnormality is particularly associated with agenesis. From Table III it will be seen that the accompanying abnormalities in this series were duodenal atresia, annular pancreas, malrotation, Meckel's diverticulum, and imperforate anus. Barium swallow may show deviation of the oesophagus to the agenetic side, particularly when the right lung is absent. Occasionally the diaphragm may be deficient on either the ipsilateral or contralateral side, allowing eventration of the abdominal viscera, but this anomaly is more often seen accompanying hypoplasia.

Spinal abnormalities. The most common associated spinal abnormality is hemivertebra which is not exclusively associated with agenesis and may occur with hypoplasia. The resultant scoliosis may be a severe additional handicap in the child already suffering from recurrent respiratory infection. Such a scoliosis may also result from a rudimentary rib on the affected side (Case 13). Abnormality of the spine or ribs in the cervical or thoracic regions may be attended by a more prominent scapula on the affected side (Fig. 4). It will be seen from Table III, that abnormalities of proper segmentation of the vertebral bodies and failure of ossification are not uncommon, and these are not just limited to the thoracic region (see Fig. 6).

Ipsilateral facial abnormalities. From Table VII, it will be noted that 6 of the 8 living cases had some associated facial or jaw abnormality, always on the ipsilateral side (see Fig. 2 and 3), which indicate

TABLE V

Cases Showing Abnormal Vascular Supply

\begin{tabular}{|c|c|c|c|}
\hline Author & & $\begin{array}{c}\text { Side of } \\
\text { Agenesis }\end{array}$ & Vascular Abnormality \\
\hline $\begin{array}{l}\text { Théremin (1884), Case } 1 \quad \ldots \\
\text { Case } 2 \ldots \\
\text { Hurwitz and Stephens (1937) } \\
\text { Castellanos and Pereiras (1942), Case } 2 \\
\text { Thomas and Boyden }(1952), \text { Case } 3 \\
\text { Maier and Gould (1953) } \ldots \\
\text { Clark, Scott, and Johnson (1955), Case } 1 \\
\text { Tezok, Balci, Alin, and Gerelioglu (1965) } \\
\text { Wheeler, Wolf, and Stevens (1966) .. }\end{array}$ & \begin{tabular}{l|}
$\cdots$ \\
$\cdots$ \\
$\cdots$ \\
$\cdots$ \\
$\cdots$ \\
$\cdots$ \\
$\cdots$
\end{tabular} & $\begin{array}{l}\text { Lt. } \\
\text { Lt. } \\
\text { Lt. } \\
\text { Lt. } \\
\text { Rt. } \\
\text { Rt. } \\
\text { Rt. } \\
\text { Lt. } \\
\text { Rt. }\end{array}$ & $\begin{array}{l}\text { Anomalous pulmonary venous drainage to azygos vein } \\
\text { Anomalous pulmonary venous drainage to azygos vein } \\
\text { Anomalous pulmonary venous drainage of lt. lung rudiment to azygos vein } \\
\text { Persistent lt. superior vena cava } \\
\text { Lt. pulmonary artery posterior to lt. bronchus } \\
\text { Aorta anterior to trachea and compressing it; lt. pulmonary artery } \\
\text { posterior to trachea } \\
\text { Anomalous pulmonary venous drainage of lt. lung to rt. atrium } \\
4 \text { pulmonary veins on rt. side } \\
\text { Lt. subclavian vein entering lt. atrium, single pulmonary vein entering rt. } \\
\text { atrium; 'pseudo-vascular ring' formed by patent ductus arteriosus' } \\
\text { compressing trachea }\end{array}$ \\
\hline
\end{tabular}




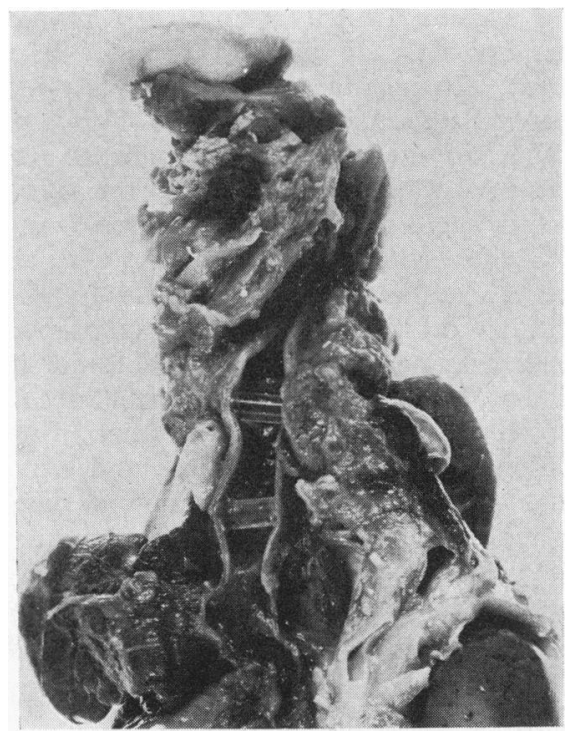

Fig. 11.-Case 1.

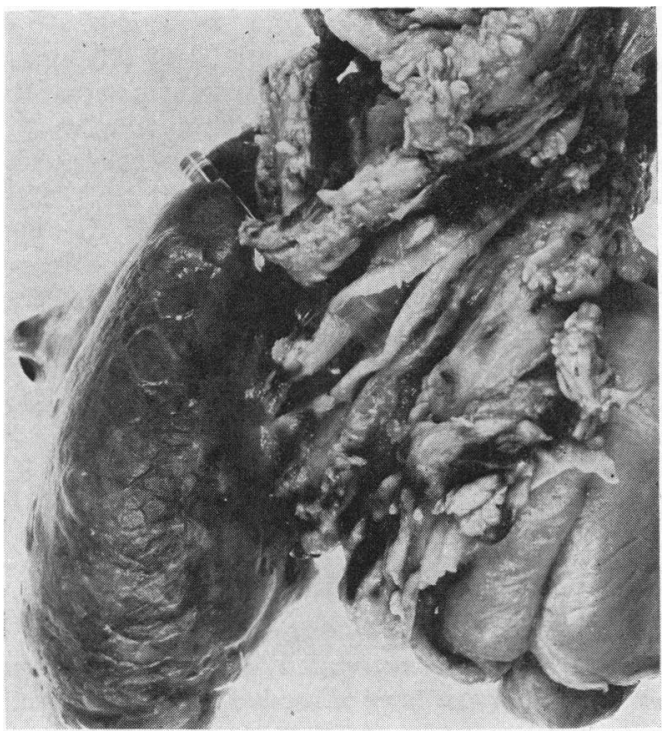

FIG. 12.-Case 4.

that such anomalies may be more common than has hitherto been recorded (Walker, 1961).

Table VII, and it is suggested that Case 13 from our series is a true example of unilateral facial agenesis or hemifacial microsomia (see Fig. 13 and 14)

\section{TABLE VI}

Cases Showing Association with Tracheo-oesophageal Fistula

\begin{tabular}{|c|c|c|c|c|}
\hline \multirow{2}{*}{ Author } & \multirow{2}{*}{$\begin{array}{l}\text { Side of } \\
\text { Agenesis }\end{array}$} & \multirow{2}{*}{$\begin{array}{c}\text { Details of } \\
\text { Tracheo-oesophageal Fistula } \\
\text { (TOF) }\end{array}$} & \multicolumn{2}{|c|}{ Associated Abnormalities } \\
\hline & & & Cardiovascular & Other \\
\hline $\begin{array}{c}\text { Klebs (1874) } \text { cited by Meyer } \\
\begin{array}{c}(1910) \\
\end{array}\end{array}$ & Lt. & $\begin{array}{l}\text { Offshoot from } \\
\text { oesophagus to } \\
\text { rudimentary lung }\end{array}$ & & \\
\hline $\begin{array}{llll}\text { Paul (1928) } & \ldots & \ldots & \ldots\end{array}$ & Lt. & $\begin{array}{l}\text { Small bronchial } \\
\text { communication from } \\
\text { hypoplastic lt. lung to } \\
\text { lower oesophagus }\end{array}$ & PDA & Limb deformities \\
\hline $\begin{array}{l}\text { Wehr (1934) cited by } \\
\text { Bonnholtzer (1938) }\end{array}$ & Lt. & $\begin{array}{l}\text { Straight through TOF; } \\
\text { atresia of larynx }\end{array}$ & VSD & $\begin{array}{l}\text { Defective lt. } \\
\text { diaphragm; spleen } \\
\text { and stomach in lt. } \\
\text { pleural cavity }\end{array}$ \\
\hline $\begin{array}{l}\text { Lelong, Vialette, Couder, and } \\
\text { Giffard (1950) }\end{array}$ & Lt. & TOF & & $\begin{array}{l}\text { Hare-lip and cleft } \\
\text { palate; absent lt. } \\
\text { kidney }\end{array}$ \\
\hline $\begin{array}{l}\text { Naclerio and Hochberg }(1950) \\
\text { Case } 1\end{array}$ & Rt. & $\begin{array}{l}\text { Normal TOF; } \\
\text { oesophageal atresia }\end{array}$ & & $\begin{array}{l}\text { Horseshoe-shaped } \\
\text { kidneys; fused lower }\end{array}$ \\
\hline $\begin{array}{c}\text { Caussade, Neimann, and } \\
\text { Bénichoux (1952) } \ldots\end{array}$ & Rt. & $\begin{array}{l}\text { Normal TOF; } \\
\text { oesophageal atresia }\end{array}$ & $\begin{array}{l}\text { ASD; lt. brachiocephalic } \\
\text { vein drained into } \\
\text { pulmonary vein }\end{array}$ & \\
\hline $\begin{array}{l}\text { Macht and Bessinger (1952), } \\
\text { cited by Valle (1955) }\end{array}$ & Lt. & TOF & & \\
\hline $\begin{array}{l}\text { Thomas and Boyden (1952) } \\
\text { Case } 2 \\
\text { Zhuchkova and Peschanskii }\end{array}$ & $\begin{array}{l}\text { Rt. } \\
\text { Rt. }\end{array}$ & $\begin{array}{l}\text { TOF } \\
\text { Normal TOF; }\end{array}$ & $\begin{array}{l}\text { Ectopic position of lt. } \\
\text { pulmonary artery } \\
\text { PDA; single ventricle }\end{array}$ & \\
\hline $\begin{array}{ccc}(1955) & \ldots & \ldots \\
\text { Caramello }(1956) & \ldots & \ldots\end{array}$ & Lt. & $\begin{array}{l}\text { oesophageal atresia } \\
\text { Normal TOF }\end{array}$ & & $\begin{array}{l}\text { Absent lt. kidney and } \\
\text { ureter }\end{array}$ \\
\hline $\begin{array}{l}\text { Smith and Bech (1958) } \\
\text { Case } 1\end{array}$ & Rt. & $\begin{array}{l}\text { Normal TOF; } \\
\text { oesophageal atresia }\end{array}$ & & \\
\hline $\begin{array}{l}\text { Warner, McGraw, Peterson, } \\
\text { Cleland, and Meyer (1961) }\end{array}$ & Rt. & $\begin{array}{l}\text { Small fistulous track } \\
\text { between oesophagus and } \\
\text { rudimentary rt. lower } \\
\text { lobe } \\
\text { Normal TOF; } \\
\text { oesophageal atresia }\end{array}$ & & $\begin{array}{l}\text { Fusion of several rt. } \\
\text { upper ribs; fusion of } \\
\text { upper two lt. ribs; } \\
\text { vertebral anomalies }\end{array}$ \\
\hline
\end{tabular}


TABLE VII

Cases Showing Associated Facial Abnormalities

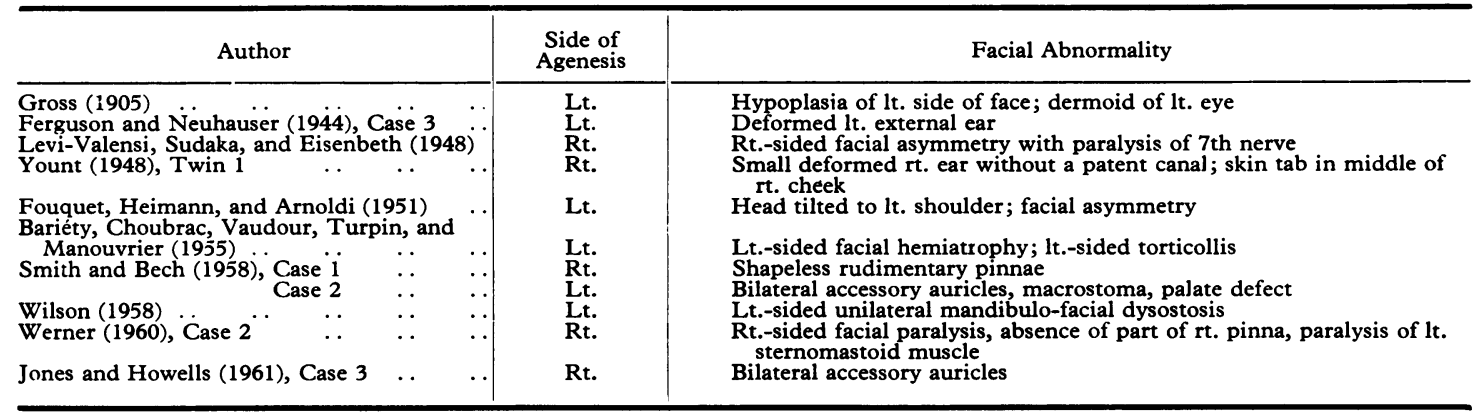

(Gorlin and Pindborg, 1964). Malocclusion was seen in 3 (Cases 12, 15, and 16).

Ipsilateral limb abnormalities. (See Table VIII.) 2 of the 8 living cases showed marked abnormality of the ipsilateral upper limb. In Case 13 (Fig. 2, 15, and 17) the whole of the left arm was noted to be smaller and less powerful, the left radius was absent, there was some bowing of the ulna, and malformation of the carpus terminating in a smaller and less powerful hand (Riordan, 1955). In Case 14, the arm was again less powerful and smaller in diameter; otherwise the arm and forearm were normally formed, but the right thumb possessed poor thenar musculature and was set further forward in a digital position; consequently, the hand spanned a note less than the full octave spanned by the left hand (Fig. 18). In Case 7, there was also digital positioning of the thumb accompanied by palmar flexion and rotation of the wrist (Fig. 16). In several of the cases recorded in Table IV, the upper clavicular head of the pectoralis major was either poor or absent on the ipsilateral side, which tended to accentuate the flatness of the chest and gave rise to a definite infraclavicular hollow (Netterville, 1957). In addition, the fibres of the trapezius muscle coming from the occipital and cervical heads were much smaller than on the normal side. Only very rarely is the ipsilateral leg involved, as in Case 7.

Cases occurring in twins. (See Table IX.) In this series, Case 1 was the liveborn of twins; the other twin though macerated showed no abnormalities. Only 5 other cases of this condition occurring in twins have been recorded, and of these only those

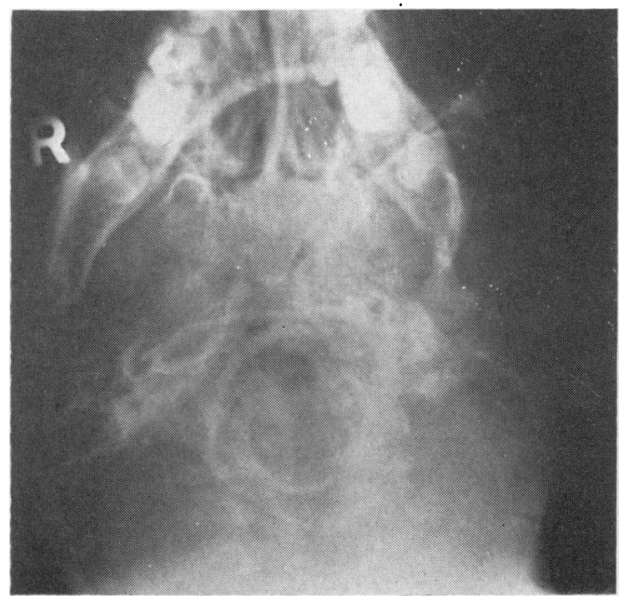

FIg. 13.-Case 13.

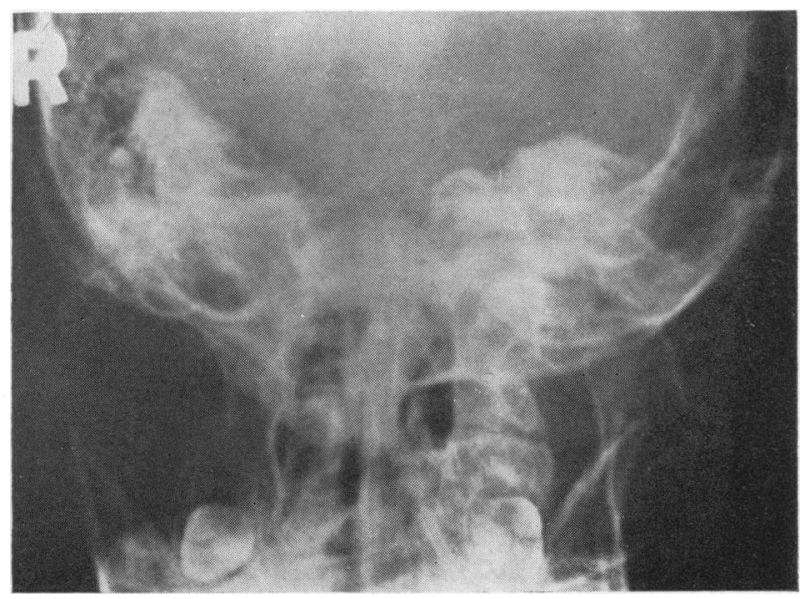

Fig. 14.-Case 13. 
TABLE VIII

Cases Showing Associated Limb Abnormality

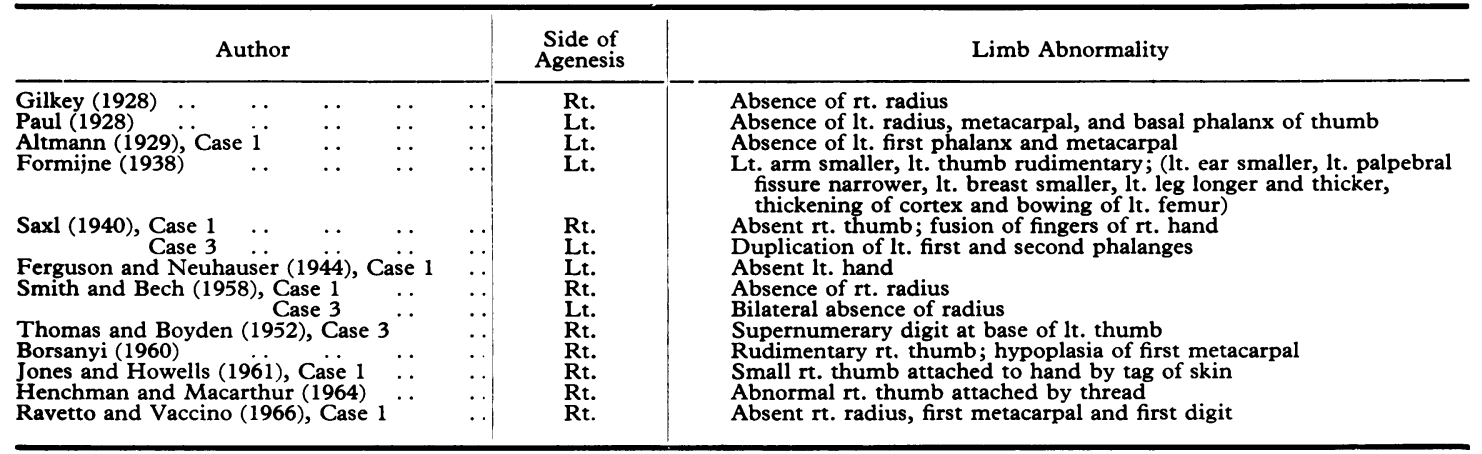

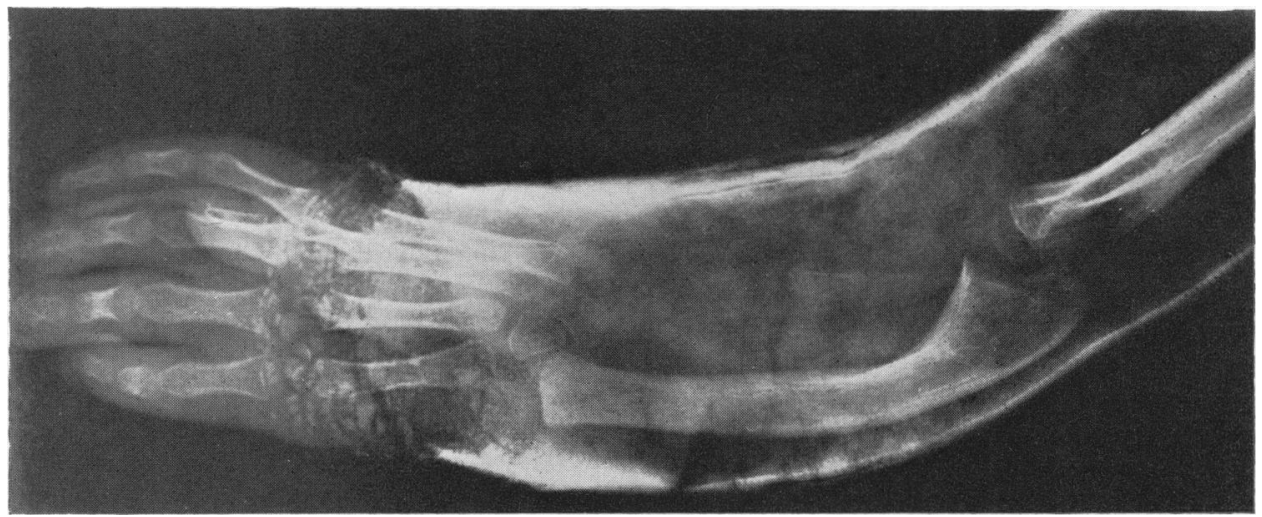

Fig. 15.-Case 13.

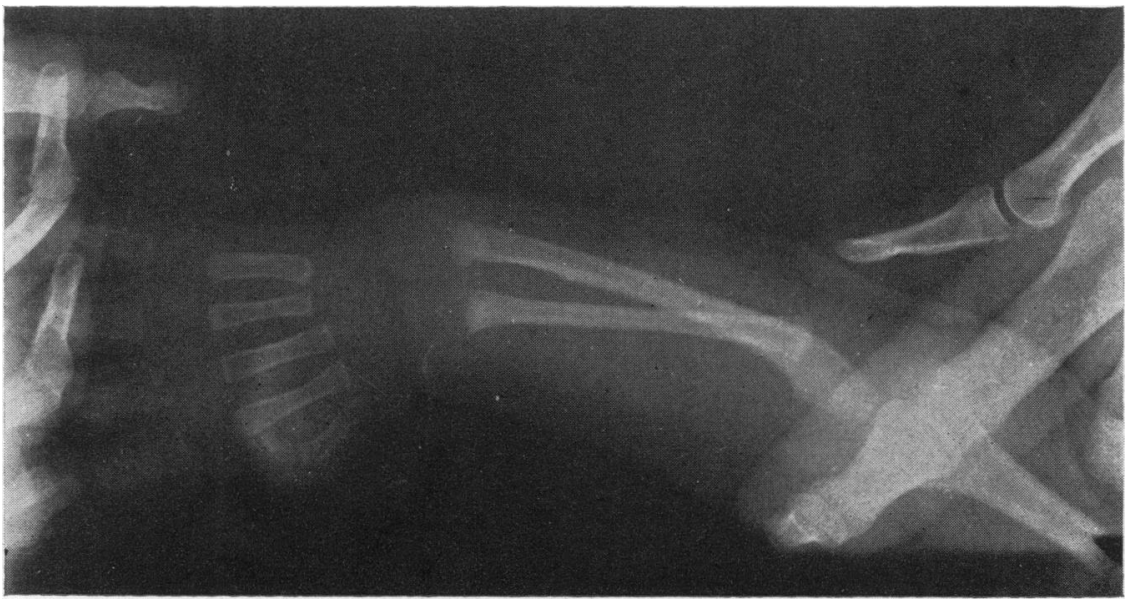

FIG. 16.-Case 7. 
TABLE IX

Cases Occurring in Twins

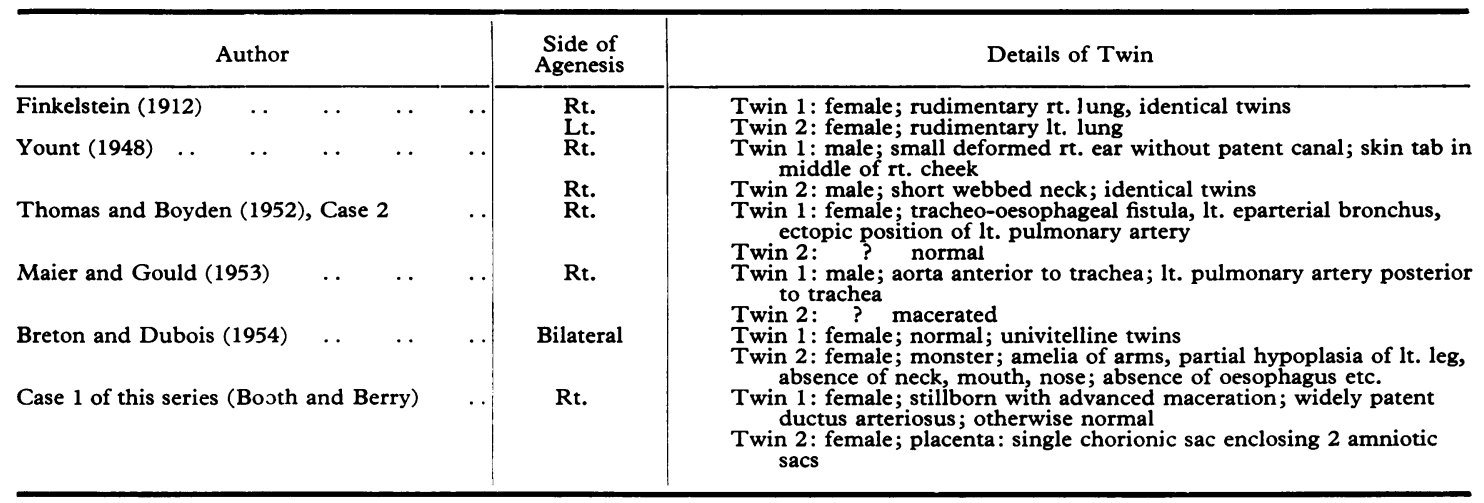

$?=$ Sex unknown

recorded by Finkelstein (1912) and Yount (1948) have shown the absence of a lung in both twins. In the twins recorded by Yount, the right lung was absent in both babies. In the twins recorded by Finkelstein the absent lung was on the right side in the first twin and on the left in the second. The disparity of the abnormality between twins is inexplicable.

Other abnormalities. Other abnormalities have been recorded, notably of the urogenital system. A small number of cases have been recorded with an absent kidney, with associated abnormalities of the ureter and of its entry into the bladder. No particular pattern is obviously associated with unilateral pulmonary agenesis, except that when a kidney is absent it is almost invariably absent on the ipsilateral side. Abnormalities of the urogenital system do not seem to predispose to a poorer prognosis. Other associated abnormalities that have been recorded with this condition are, harelip, cleft palate, dislocated hips, perforated nasal septum, hydrocephalus, absent ipsilateral ovary, unicornuate uterus, and double uterus and vagina.

\section{Pathogenesis}

Embryology. The tracheo-bronchial groove appears in the fourth week of foetal life as a median ventral diverticulum of the fore-gut. The groove deepens and eventually becomes a tube. A longitudinal groove appears in each lateral wall of this tube and the ridges thus formed in the lumen fuse, separating the oesophagus and trachea. Before this separation has occurred the lung buds develop from the caudal end of its 'tracheal' aspect.

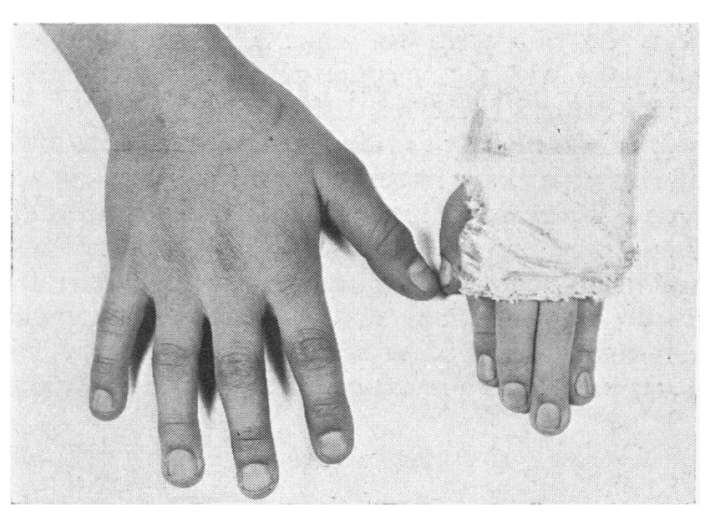

FIG. 17.-Case 13.

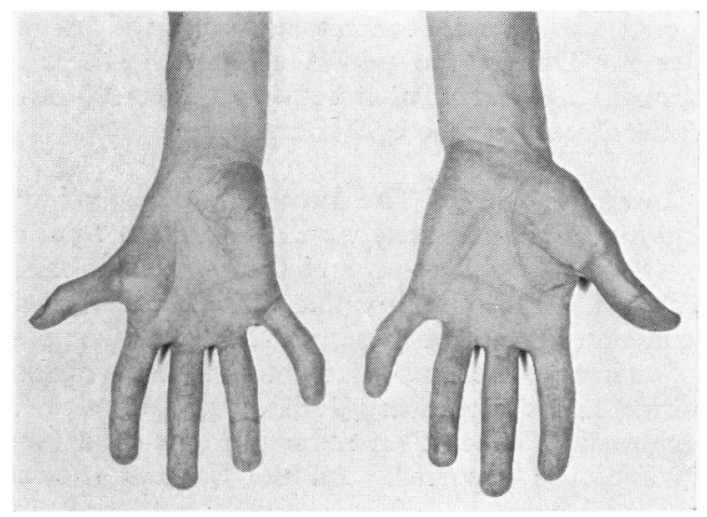

FIG. 18.-Case 14. 
TABLE X

Lung Function Tests (volumes expressed in litres)

\begin{tabular}{|c|c|c|c|c|c|c|c|c|c|c|}
\hline \multirow{2}{*}{$\begin{array}{l}\text { Case } \\
\text { No. }\end{array}$} & \multirow{2}{*}{$\begin{array}{c}\text { Age } \\
\text { (yr.) }\end{array}$} & \multirow{2}{*}{$\underset{\text { (m.) }}{\text { Height }}$} & \multirow{2}{*}{$\begin{array}{c}\text { Weight } \\
\text { (kg.) }\end{array}$} & \multicolumn{4}{|c|}{ Expected } & \multicolumn{3}{|c|}{ Actual } \\
\hline & & & & $\mathrm{FEV}_{1}$ (Ht.) & FVC (Ht.) & $\mathrm{FEV}_{1}$ (age) & FVC (age) & $\mathrm{FEV}_{1}$ & FVC & $\%$ Ratio \\
\hline $\begin{array}{l}10^{\star} \\
12 \\
13 \\
14 \\
15 \\
16 \\
17 \\
18^{\star}\end{array}$ & $\begin{array}{c}4 \frac{1}{2} \\
7 \frac{1}{2} \\
12 \\
17 \frac{1}{2} \\
18 \\
19 \\
23 \\
6 \frac{3}{4}\end{array}$ & $\begin{array}{l}0.97 \\
1.25 \\
1.45 \\
1.73 \\
1.84 \\
1.62 \\
1.55 \\
1.05\end{array}$ & $\begin{array}{l}14 \cdot 5 \\
18.5 \\
37.5 \\
52 \cdot 5 \\
66 \cdot 0 \\
60 \cdot 0 \\
54 \cdot 5 \\
17 \cdot 5\end{array}$ & $\begin{array}{r}1-6 \\
2 \cdot 2 \\
4 \cdot 0 \\
4 \cdot 5 \\
3 \cdot 3 \\
2 \cdot 8 \\
-\end{array}$ & $\begin{array}{r}-1 \cdot 8 \\
2 \cdot 5 \\
4 \cdot 8 \\
5 \cdot 2 \\
3 \cdot 7 \\
3 \cdot 2 \\
-\end{array}$ & $\begin{array}{r}-\overline{5} \\
2 \cdot 4 \\
3 \cdot 4 \\
4 \cdot 5 \\
3 \cdot 6 \\
3 \cdot 6 \\
-\end{array}$ & $\begin{array}{r}-\overline{1} \cdot 7 \\
2 \cdot 8 \\
3 \cdot 8 \\
5 \cdot 0 \\
4 \cdot 0 \\
4 \cdot 0 \\
-\end{array}$ & $\begin{array}{l}0 \cdot 4 \\
0.9 \\
1 \cdot 5 \\
2 \cdot 1 \\
2 \cdot 3 \\
1 \cdot 3 \\
1 \cdot 4 \dagger \\
0.7\end{array}$ & $\begin{array}{l}0.4 \\
1.3 \\
1 \cdot 7 \\
2 \cdot 7 \\
3.2 \\
1 \cdot 7 \\
-0.8\end{array}$ & $\begin{array}{r}100 \\
69 \\
88 \\
77 \\
72 \\
76 \\
82\end{array}$ \\
\hline
\end{tabular}

* No normal values available below age of 7 .

† Value unreliable due to patient's mental state; FVC could not be recorded.

The fusion of the ridges extends cranially, but at the cephalic end a communication with the pharynx remains (Broman, 1923). The association of tracheo-oesophageal fistula with agenesis of the lung is thus readily explained.

At the $5 \mathrm{~mm}$. stage, a pair of branchial arteries (the 6th) appear and supply the lung buds. Necrosis of an established lung bud may be considered as a possible mode of causation of this defect; if so, it presumably occurs at about this time. It is harder to explain the associated somatic and renal anomalies, but presumably an adverse factor is acting on embryogenesis at the 3-5 $\mathrm{mm}$. stage.

Development of lung. The existing lung may show infinite variety in its state of development, ranging from being unilobar to having a greater number of lobes than normal. The bronchus may vary considerably in its point of entry, and under these conditions a left eparterial bronchus, bronchi arising above the carina, and also both main bronchi entering the same lung, have all been recorded. After birth, the alveolar volume increases until adult life. During the first 8 years this is due to continued alveolar development, but after that age it occurs as a result of increasing volume of existing alveoli. During the period of growth, there is normally a linear relation between the surface area of the alveoli and the body surface area.

Lung function. The forced expiratory volume and forced vital capacity were measured in 7 out of the 8 cases at follow-up and the results shown in Table X. This confirms that there is a significant reduction in both of these measurements, but that in each case the ratio of the two remains within normal limits (Rosenberg, 1962), suggesting that no abnormality, other than reduction of a total lung volume, has occurred. All the 8 cases showed marked dyspnoea after exercise sustained for approximately half an hour, but no dyspnoea under ordinary circumstances, suggesting that the rate of accumulation of oxygen debt was raised.

There was no evidence of secondary polycythaemia in any case.

\section{Prognosis}

The side of the agenesis affects prognosis. In our series in 7 of the 9 deaths, the right lung was absent; in 6 of the 8 living patients, the left lung was absent. The sexes were almost equally represented. These figures confirm the findings of previous authors; that is, the condition has a poorer prognosis when the right lung is absent (Schaffer and Rider, 1957), apparently due to the associated anomalies. It can be seen from Table III, that an accompanying heart abnormality is more commonly associated with right-sided agenesis.

Out of the 9 cases in Table III, only 1 lived longer than a year; of the remainder, 2 lived less than a week, and 3 lived for $2 \frac{1}{2}$ months. Furthermore, of the 9 deaths, 5 had an associated cardiac abnormality, whereas in the living series there was only one such case-apparently when there is an associated cardiac abnormality the prognosis is considerably more grave.

Associated abnormalities of other systems of the body do not seem to indicate a similarly poor prognosis, with the exception of malformations of the spinal column (Marioni, 1962).

It is immediately obvious that any infection of the one lung may have its serious consequences. When type 3 agenesis or hypoplasia is present the lung tissue may become the site of recurrent infection and consequently its removal becomes essential. Recurrent infection or an associated cardiac abnormality may cause finger clubbing, but this is never present as a result of uncomplicated agenesis.

\section{Summary}

Seventeen cases of unilateral pulmonary agenesis are described and illustrated. The abnormalities 
that they show have been compared with those recorded for other patients in the literature to demonstrate both the characteristic features of the condition and the associated generalized developmental defects. An increased percentage of ipsilateral anomalies is recorded. Lung function tests have been carried out on 7 of the 8 living patients, and confirm that in agenesis of the lung, the growth of the existing lung provides adequate pulmonary function, but that a reduction in vital capacity and exercise tolerance can be demonstrated.

The work was supported in part by a grant from The Joint Research Board of The Hospital for Sick Children and The Institute of Child Health. Our thanks are due to Dr. A. E. Claireaux and Dr. R. E. Bonham Carter for their criticism and advice in the preparation of the manuscript.

We wish to thank the Physicians and Surgeons of The Hospital for Sick Children for permission to publish details of cases under their care, and also Professor C. E. Field and Dr. F. S. W. Brimblecombe for kindly allowing us to review the cases they had reported previously. We should like to acknowledge the help given to us by the Department of Medical Illustration and also to Mr. Patrick Clarkson for allowing us to include Fig. 13, 14, and 15, and to Miss E. Glover, Miss I. Fyne, and Mrs. G. Wreakes for secretarial assistance.

(We regret that a full follow-up was not possible on Case 11.)

\section{REFERENCES}

Altmann, F. (1929). Zur Kenntnis der Lungenhypoplasien. Z. Anat. Entwickl.-Gesch., 88, 500.

Bariéty, M., Choubrac, P., Vaudour, P., Tupin, J., and Manouvrier, F. (1955). Sur un cas d'agénésie pulmonaire, diagnostiquée chez l'adulte par l'angiographie. Bull. Mém. Soc. Méd. Hôp. Paris, 71, 471.

Borsanyi, S. (1960). Agenesis of the lung. Laryngoscope (St. Louis), 70, 187.

Boyden, E. A. (1955). Developmental anomalies of the lungs. Amer. F. Surg., 89, 79.

Breton, A., and Dubois, O. (1954). Agénésie et hypoplasie pulmonaires. Pédiatrie, 9, 803.

Brimblecombe, F. S. W. (1951). Pulmonary agenesis. Brit. F. Tuberc., 45, 7 .

Broman, I. (1923). Zur Kenntnis der Lungenentwicklung. I. Wann und wie entsteht das definitive Lungenparenchym? Verh. anat. Ges. (fena), 32, 83.

Caramello, M. T. G. (1956). L'agenesia del polmone. Contributo statistico e clinico. Lattante, 27, 803.

Castellanos, A., and Pereiras, R. (1942). Pulmonary agenesia. Bol. Soc. cuba. Pediat., 14, 268.

Caussade, L., Neimann, N., and Bénichoux, R. (1952). Agénésie d'un poumon associée à une atrésie de l'oesophage et à d'autres malformations cardio-vasculaires. Arch. franc. Pédiat., 9, 89.

Clark, H., Scott, R. B., and Johnson, J. B. (1955). Pulmonary agenesis. Pediatrics, 15, 761.

Delarue, J., Paillas, J., Abelanet, R., and Chomette, G. (1959). Les broncho-pneumopathies congénitales. Bronches, 9, 114.

Ferguson, C. F., and Neuhauser, E. B. D. (1944). Congenital absence of the lung (agenesis) and other anomalies of the tracheobronchial tree. Amer. F. Roentgenol., 52, 459.

Field, C. E. (1946). Pulmonary agenesis and hypoplasia. Arch. Dis. Childh., 21, 61.

Finkelstein, H. (1912). Hypoplasie und Agenesie der Lunge. In Lehrbuch der Säuglingskrankheiten, p. 634. Fischer's Medizin, Berlin.
Formijne, P. (1938). Agenesie en hypoplasie der longen. Ned. T. Geneesk., 82, 5482.

Fouquet, J., Heimann, V., and Arnoldi (1951). Agénésie totale du poumon gauche bien tolérée chez une filette de 12 ans. Bull. Mém. Soc. Méd. Hôp. Paris, 67, 1084.

Gilkey, H. M. (1928). Congenital absence of lung: report of a case. 7. Mo. med. Ass., 25, 296.

Gorlin, R. J., and Pindborg, J. J. (1964). Syndromes of the Head and Neck, p. 261. McGraw-Hill, New York.

Gross, W. (1905). Ein Fall von Agenesie der Linken Lunge. Beitr. path. Anat., 37, 487.

Henchman, D. C., and Macarthur, E. B. (1964). Agenesis of the right lung: report of a case. Med. F. Aust., 2, 675.

Hurwitz, S., and Stephens, H. B. (1937). Agenesis of the lung. Amer. F. med. Sci., 193, 81.

Ingram, M. D., Jr., Hudson, G. W., and Davis, T. J. (1950). Aplasia of the lung. Amer. F. Roentgenol., 64, 409.

Jimenez-Martinez, M., Pérez-Alvarez, J. J., Pérez-Treviño, C., Rubio-Alvarez, V., and De Rubiens, J. (1965). Agenesis of the lung with patent ductus arteriosus treated surgically. f. thorac. cardiovasc. Surg., 50, 59.

Jones, H. E., and Howells, C. H. L. (1961). Pulmonary agenesis. Brit. med. F., 2, 1187.

Klebs, E. (1874). Missbildungen der Lunge. Aerztl. Cor.-Bl. Bohmen, 2, 111. (Cited by Meyer, O., 1910, Arch. Entwickl.Mech. Org., 30, 342.)

Lelong, M., Vialette, J., Couder, F., and Giffard, E. (1950). Un cas d'absence congénitale du poumon gauche avec autres malformations homolatéral. Bull. Mém. Soc. Méd. Hôp. Paris, 66, 715.

Levi-Valensi, A., Sudaka, P., and Eisenbeth, R. (1948). Agénésie bronchique droite chez un enfant de cinq ans constatée par bronchoscope. ibid., 64, 749.

Lukas, D. S., Dotter, C. T., and Steinberg, I. (1953). Agenesis of the lung and patent ductus arteriosus with reversal of flow. New Engl. F. Med., 249, 107.

Maier, H. C., and Gould, W. J. (1953). Agenesis of the lung with vascular compression of the tracheobronchial tree. $\mathcal{f}$. Pediat., 43, 38.

Maisano, A. (1965). Le agenesie polmonari. Arch. Chir. Tor., 22, 409.

Marioni, P. (1962). Agenesis of the lung. Dis. Chest, 41, 232.

Naclerio, E. A., and Hochberg, L. A. (1950). Congenital absence of lung. N.Y. St. F. Med., 50, 1267.

Nelson, C. S., McMillan, I. K. R., and Bharucha, P. K. (1967). Tracheal stenosis, pulmonary agenesis and patent ductus arteriosus. Thorax, 22, 7.

Netterville, R. E. (1957). Agenesis of the lung. Dis. Chest, 31, 457.

Nicks, R. (1957). Agenesis of the lung with persistent ductus arteriosus. Thorax, 12, 140.

Oyamada, A., Gasul, B. M., and Holinger, P. H. (1953). Agenesis of the lung. Amer. F. Dis. Child., 85, 182.

Paul, F. (1928). Fehlbildungen im Bereiche der Atmungsorgane. Virchows Arch. path. Anat., 267, 295.

Ravetto, F., and Vaccino, P. (1966). L'agenesis polmonare. Minerva pediat., 18, 269.

Riordan, D. C. (1955). Congenital absence of the radius. F. Bone ft Surg., 37A, 1129.

Rosenberg, D. M. L. (1962). Pulmonary agenesis. Dis. Chest, 42, 68.

Saxl, O. (1940). Beitrag zur Diagnose der Lungenagenesie. Ann. paediat. (Basel), 154, 180.

Schaffer, A. J., and Rider, R. V. (1957). A note on the prognosis of pulmonary agenesis and hypoplasia according to the side affected. f. thorac. Surg., 33, 379.

Schneider, P. (1912). Die Missbildungen der Atmungsorgane. In Die Morphologie der Missbildungen des Menschen und der Tiere, ed. E. Schwalbe, III Teil 2 Abteil, Kapitel VIII, pp. 817-822. G. Fischer, Jena.

Smart, J. (1946). Complete congenital agenesis of a lung. Quart. F. Med., (n.s.), 15, 125.

Smith, R. A., and Bech, A. O. (1958). Agenesis of lung. Thorax, 13, 28.

Steinberg, I., and Stein, H. L. (1966). Angiocardiography in diagnosis of agenesis of a lung. Amer. F. Roentgenol., 96, 991.

Tezok, F., Balci, K., Alin, H., and Gerelioglu, Y. (1965). Un cas d'hypoplasie totale du poumon gauche. Rev. méd. Moy. Or., 22, 451. 
Théremin, E. (1884). Deux cas d'absence congénitale du poumon gauche. Rev. mens. Mal. Enf., $2,554$.

Thomas, L. B., and Boyden, E. A. (1952). Agenesis of the right lung. Surgery, 31, 429.

Tosi, G., and Ziliotto, G. R. (1964). Agenesia del polmone destro associata a malformazioni dei bronchi del polmone sinistro e ad altre alterazioni di prima formazione. Riv. Anat. pat., 25, ccix.

Valle, A. R. (1955). Agenesis of the lung. Amer. F. Surg., 89, 90.

Walker, D. Greer (1961). Malformations of the Face, p. 104. E. \& S. Livingstone, Edinburgh and London.

Warner, F. S., McGraw, C. T., Peterson, H. G., Jr., Cleland, R. S., and Meyer, B. W. (1961). Lung ectopia and agenesis with heart dextrorotation. Amer. F. Dis. Child., 101, 514.

Wehr, C. (1934). Beiträge zur Kenntnis der Entwicklungsstörungen der Atmungsorgane (Lungenägenesie, Kehlkopfatresie) und des Zwerchfalls. Inaug.-Diss. Pieper, Göttingen. (Cited by Bonnholtzer, E., 1938, Beitrag zur Kenntnis einseitiger Lungenagenesien. Beitr. path. Anat., 101, 614.)

Werner, M. J. (1960). Le diagnostic bronchoscopique et bronchographique de l'agénésie du poumon chez le nourisson. Ann. Oto-laryng. (Paris), 77, 211.
Wexels, P. (1951). Agenesis of the lung. Thorax, 6, 171.

Wheeler, P. C., Wolff, L. J., and Stevens, E. M. (1966). Pseudovascular ring resulting from right lung agenesis, normal aortic arch, and patent ductus arteriosus. Amer. F. Roentgenol., 98, 365.

Wilson, T. G. (1958). A case of unilateral mandibulo-facial dysostosis associated with agenesis of the homolateral lung. f. Laryng., 72, 238.

Yount, F. (1948). Agenesis of the right lung in each of identical twins. Ariz. Med., 5, (5) 48.

Zhuchkova, V. V., and Peschanskii, V. S. (1955). Agenesis of the lung and atresia of the oesophagus in the newborn. [In Russian.] Pediatriya, no. 6, 57.

\section{Addendum}

Since this paper was written a further patient has been seen, whose details have been included as Case 18 in Table $\mathrm{X}$; he has no ipsilateral associated abnormalities. 